sciendo Порівняльна професійна педагогіка 9(4)/2019 Comparative Professional Pedagogy 9(4)/2019

DOI: $10.2478 /$ rpp-2019-0031

Corresponding Member of National Academy of Pedagogical Sciences of Ukraine, Doctor of Science in Special Education, Full Professor, ANDRII HARRY SHEVTSOV National Pedagogical Drahomanov University Address: 9 Pyrohov St., Kyiv, 01601, Ukraine

E-mail: dr_shevtsov@ukr.net

$\mathrm{PhD}$ in Pedagogy, Associate Professor, Postdoctoral Researcher in Special Education, NATALIIA NYKONENKO National Pedagogical Drahomanov University Address: 9 Pyrohov St., Kyiv, 01601, Ukraine E-mail: nataliianykonenko@gmail.com

\title{
METHODOLOGICAL FOUNDATIONS OF EDUCATIONAL COMPARATIVE STUDIES ON SPECIAL EDUCATION TEACHERS' PREPARATION: FOREIGN EXPERIENCE
}

\begin{abstract}
Carrying out a research within the field being a part of a meta-science, which has the object of the whole education system with relevant educational processes at different levels, educational institutions, factors, dominant and trends in its development, resources, including human capital, and other elements together with the mechanisms of interaction between them, we use the term "educational comparative studies" as more adequate to define the research field mentioned above. It is stated that modernization of the national educational system in Ukraine in the framework of the world mainstream is not possible without unified and well-defined terminological bases, methodological foundations, principles and criteria for comparative studies that meet the current level of the science development and the needs of society. It is proved that the most effective way of fulfillment a comparative analysis of education systems in different countries is a detailed study of theory and practice of their teachers' preparation for the systems under consideration. Having analyzed different scientific approaches to identifying criteria for a comparative study, the criteria on the development of teachers' preparation are introduced. It is highlighted that the defined criteria will be applied in the research work on the development of special education teachers' preparation systems in the USA, the UK and Ukraine. They are introduced in the article: legal support of the educational system for individuals with special needs; national and regional standards of special education teachers' preparation; curriculums, methods, and technologies for special education teachers' preparation; system of retraining and licensures of special education teachers; informative and scientific subsystem of special education system; subsystem of special education teachers' pre-service preparation and in-field practical work management; financial and economic subsystem of training and retraining of special education teachers.

Keywords: special education, special education teachers' preparation system, individuals with disabilities teaching; individuals with special educational needs, educational comparative studies, special education teachers' preparation in the USA, special education teachers' preparation in the UK.
\end{abstract}


sciendo Порівняльна професійна педагогіка 9(4)/2019 Comparative Professional Pedagogy 9(4)/2019

\section{АНОТАЦІЯ}

Проводячи дослідження у галузі, яка є складовою мета-науки, предметом якої виступає иілісна система освіти з відповідними освітніми прочесами на різних рівнях, закладами освіти, чинниками, домінантами та тенденціями ї̈ розвитку, ресурсами, включаючи людський капітал та інші елементи разом з механізмами взаємодї між ними, ми вживатимемо термін «освітня компаративістика» як такий, щуо більше відповідає згаданій вище сфері дослідження. Зазначається, щяо модернізація національної системи освіти в Украӥні в рамках світових тендениій неможлива без уніфікованих та чітко визначених термінологічних основ, методологічних засад, принципів та критеріїв порівняльних досліджень, щзо відповідають сучасному рівню розвитку науки та потребам суспільства. Доведено, що найефективнішим способом виконання порівняльного аналізу систем освіти в різних країнах $\epsilon$ детальне вивчення теорії та практики підготовки їх викладачів до систем, щзо розглядаються. Визначено критерії порівняння систем підготовки вчителів спеціальної освіти у США, Великої Британії та Україні: нормативноправове забезпечення системи освіти осіб із особливими освітніми потребами; начіональні та регіональні стандарти підготовки вчителів для системи освіти осіб із особливими освітніми потребами; методи, засоби, технологї̈, програми підготовки вчителів системи освіти осіб із особливими освітніми потребами; система перепідготовки та сертифікації (акредитації) вчителів системи освіти осіб із особливими освітніми потребами; інформачійно-наукове забезпечення системи освіти осіб із особливими освітніми потребами; підсистема управління підготовкою та практичною роботою вчителів системи освіти осіб із особливими освітніми потребами; фінансово-економічний супровід підготовки та перепідготовки вчителів системи освіти осіб із особливими освітніми потребами.

Ключові слова: спеціальна освіта, система підготовки вчителів спеціальноӥ освіти, осіб із особливими освітніми потребами, педагогічна компаративістика, підготовка вчителів спеціальної освіти в США, підготовка вчителів спеціальної освіти у Великої Британії.

\section{INTRODUCTION}

Due to Ukraine's geopolitical location at the intersection of the paths of European and Asian globalization of cultural, economic and political processes we believe it is particularly acute for our country. For many centuries, Ukraine has been under the influence of historical, cultural and socio-political development of the Western and Eastern countries as well as influenced this process itself.

In our country, national dignity and unique national traditions in the field of education and culture have been formed, whose strengthening and preservation, however, should lead not to isolation but to globalization, which has become an objective trend of the modern world. At this new stage, the world economy functions as a single organism, enhances world division of labor, and intensifies cultural ties. The conclusion of B. Woolson (2003, p. 104) about the inability to slow it down or stop seems quite obvious. That is why the primary task of scientists is to find ways to exploit the positive possibilities of globalization for the benefit of humanity and to minimize any negative aspects and consequences. We are convinced that a scientifically balanced, creative mastery of the best samples of foreign experience, conducted at a high level of methodological culture and a clear understanding of national specifics, taking into account the profound changes that 
have taken place and continue to take place in our country for the last century, is crucial for the modernization of the national educational system in Ukraine. The latter is not possible without unified and well-defined terminological bases, methodological foundations, principles and criteria for comparative studies that meet the current level of the science development and the needs of society, the definition of which is the purpose of our research.

\section{THE AIM OF THE STUDY}

The paper aims to analyze current approaches and tasks of educational comparative studies, to define the components of a comparative research on the system of special education teacher preparation abroad providing some samples from US experience.

\section{THEORETICAL FRAMEWORK AND RESEARCH METHODS}

The basic theoretical concept of our research is a hypothesis that the most effective way of fulfillment a comparative analysis of education systems in different countries is a detailed study of theory and practice of their teacher preparation for the systems under consideration. In addition, it is necessary to distinguish the components which could allow to evaluate advantages and disadvantages of these systems and will serve reliable criteria of their development for a long time. In our comparative study we observe the most effective methodological approaches available in the field (A. Andreyev (2002), Ph. H. Coombs (1968), O. Lokshyna (2014), V. Luhovyi (1994), V. Ogneviuk (2012), I. Podlasyi (1999), I. Rachenko (1989), A. Sbrueva (1999), V. Slastenin (2002), A. Shevtsov (2009), S. Sysoyeva (2014) and many otheru).

Studies in comparative pedagogy are common among scientific researches fulfilled either in Ukraine or abroad. At various times, significant contributions to the formation and development of this science were made by C. Allaf, G. Bereday, N. Bidyuk, M. Bray, B. Holmes, A. Kazamias, G. P. Kelly, M. Crossley, V. Luhovyi, O. Lokshyna, K. Schwartz, S. Sysoyeva, B. Woolfson and many others. The necessity of carrying out the researches on domestic and foreign experience correlation is substantiated in their works, which B. Woolson (2003) mentioned to be the most important theoretical and methodological problem of comparative pedagogy.

Research methods include the individualization and systematization of the foreign experience.

\section{RESULTS}

Outlining the field of scientific knowledge, Svitlana Sysoieva (2014) examines comparative pedagogy in the context of the development of a scientific field called educology ( $u k r$. osvitologiya), the concept of which was independently elevated to the domestic scientific literature by V. Luhovyi in 1994 (1994, p. 16) and V. Ogneviuk in 1995 (2012). The scientists used this term to introduce in Ukraine the field of educatology that Elizabeth Steiner proposed in 1964 in her study "The Logic of Learning and Education", and herself reduced to "educology" to define the science, the object of which is 'all about education'. In the modern sense of educology, it integrates philosophical, scientific and praxeological knowledge of education.

It is obvious that "comparative pedagogy", as an area of integrated comparative study of educational processes on different markers at interdisciplinary and multidisciplinary levels, doesn't use pedagogical criteria only, but andragogic, economical, legislative, sociological, historical ones as well. That explains the reason for it not to be considered as a scientific field of pedagogy or its subdivision.

In fact, this field of research stands on a par with pedagogy being a part of a metascience, which has the object of the whole education system with relevant educational 
sciendo Порівняльна професійна педагогіка 9(4)/2019 Comparative Professional Pedagogy 9(4)/2019

processes at different levels, educational institutions, factors, dominant and trends in its development, resources, including human capital, and other elements together with the mechanisms of interaction between them. Therefore, we are more inclined to refer to the term "educational comparative studies" as more adequate to define the research field mentioned above.

It should be noted that the methodological foundations of this field have evolved significantly from the historical-humanistic approach to comparative educational research and finally to the application of the "scientific paradigm" ones, as noted by Ukrainian researcher of educational comparative studies O. Lokshyna (2014).

The first approach was "too high quality and intuitive" and did not meet "solid" scientific principles, which require accurate research technologies, evidence testing hypotheses, prognostic functions, valid indicators, etc. However, as a result of the discussion between "humanist historians" and "scientists", the methodology of educational comparative studies has come up with a research algorithm that "combines historical and scientific paradigms, anticipating specific educational phenomena understanding and explanation at the beginning, and then "analyzing, directed to determine the essence of the education system" (Lokshyna, 2014). George Bereday and his followers called this approach "inductive" as it directed the movement of scientific thought from concrete to general. At the same time, according to O. Lokshyna (2014), B. Holmes insisted on a thorough theoretical basis of the initial research and proposed a "hypothetical-deductive" approach as more valid.

After all, having "recovered" from structural functionalism in the 1970s, educational comparative theory has taken an integrative approach that considers educational phenomena in historical, social, economic and cultural contexts, and, in particular, aims at the results in a prognostic and practically advising manner.

Having the mentioned ideas in mind, we are outlining our thoughts on the recommended parameters for comparative scientific study of certain components of an education system in a country.

Now we need to answer the question: what should be the key link, grasping at which one can pull out the whole chain of research within educational comparative studies? Obviously, the major component of an education system, its cornerstone is human capital, as the major factor in directing its development.

Whereas human capital theory (Nobel laureates Theodor Schultz, Gary Becker, Simon (Semen) Kuznets), developed in particular by the World Bank experts for economic research, has been the theoretical basis of comparative studies since the 1990s, it seems that the subjects of the educational process, its stakeholders - school, college and university teachers, and the quality of their preparation - are the component, researching of which can make a meaningful contribution to the branch of educational comparative studies in general.

Furthermore, the history of education for people with disabilities, comparative aspects and statistical realities, as well as the training of teaching staff to work with students with special educational needs, have traditionally been considered the starting point of American studies in special education. Therefore, in order to find out the peculiarities of the development of the special education system abroad, we can consider it in the of personnel preparation context as its subsystem. So, we need to outline the principles and patterns of such research within educational comparative studies and to determine the criteria and parameters for comparing practices for the special education teachers' preparation, including the inclusive education subsystem. 
With regard to the subject of educational comparative studies, S. Sysoyeva (2014) states that "analysis of different concepts of comparative pedagogy in their historical development shows that comparative pedagogy has developed and established itself as an interdisciplinary science, the researches in which have always been clearly contextual". She also mentions that "the subject of comparative pedagogy, like pedagogy as a whole, is quite broad." However, we seek to direct and, in a certain way, narrow down the subject matter of our research, thus leaving its object broad.

At the same time, we agree with the thesis that while defining the object of educational comparative studies, we must take into account the aspects of the educational system development in the context of global, regional, and local levels of development. For our special education teacher preparation studies, we consider the most informative way to compare special education teacher system in Ukraine with the experience of the most developed countries in the world - the United States of America with their 120-year experience of educating children with disabilities in public schools, and the United Kingdom known as the educational flagship of Europe.

In our opinion, the most striking marker of the pedagogical education development is the indicators of its development in the field of training for the special education system and inclusive educational institutions, the system of social rehabilitation of children and adults with disabilities. To cite this example, in 2001, the United States adopted the "No Child Left Behind Act" (2001), which assured that all students could meet a certain educational standard by introducing feasible goals. According to this law, special education students got an equal, fair and significant opportunity to obtain a high-quality education and had to follow the same educational standards to prove their academic achievement. This was a major impetus for providing access to the public-school curriculum for all students with disabilities. The easiest way to achieve this was to intensify inclusive education.

The academic achievements of students, in particular students with special educational needs, depends to a large extent on the ability of the educational institution to involve a strong team of highly qualified professionals in the educational process. Then preparation of pedagogical staff for special education is of utmost importance, especially nowadays, during the modernization of Ukrainian education system, with the aim of adhering to the current world standards of education, which places new demands on educational institutions of all levels.

Therefore, not only the foresight of the chosen educational reform strategies, but also the understanding of the prospective goal by all participants of the educational process is urgently needed to produce positive results. That is why we consider it appropriate to compare the experience of organizing special education teacher preparation in the United States and the United Kingdom, whose experience on special education has been actively implementing in Ukraine without proper scientific analytics, which is able to follow the effective steps of the leading education systems of the world, avoiding possible problems.

Due to the widespread practice of creating an inclusive educational environment for children and adults with special educational needs in Ukraine, reforming the system of boarding schools, the processes of deinstitutionalization in the implementation of foreign experience, a lot of tasks related to the educational comparative studies need to be solved. These include: definition of criteria for comparison and equivalence of foreign and domestic conditions of socio-economic and cultural development; proving the comparability of the studied educational phenomena in different countries; identification of global patterns and trends in the development of education abroad as a whole and its various branches; 
sciendo Порівняльна професійна педагогіка 9(4)/2019 Comparative Professional Pedagogy 9(4)/2019

determining the methodology of applying foreign experience and finding out the expediency of transferring of the discovered experience and models of different educational units of other countries to our country.

The solution of these and similar problems, in fact, substantiates from a scientific point of view the possibility of implementing relevant foreign experience, carrying out prognostic analysis and developing recommendations for the development of the latest educational policy and modernization of the education system, in our case - for the system of special education and inclusive educational institutions, social rehabilitation children and adults with special educational needs.

Non-systematic implementation of foreign educational experience without proper justification for using the methodology of comparative theory can (and has already led) to the unpredictable consequences of a negative grade. The plans for the total closure of special educational institutions in accordance with foreign experience, which have been announced by the Ministry of Education and Science of Ukraine, confirm this.

Since 1990, under "Individuals with Disabilities Education Act" (IDEA) (2004) the term "special education" means "specially designed instruction, at no cost to parents, to meet the unique needs of a child with a disability, including instruction conducted in the classroom, in the home, in hospitals and institutions, and in other settings". According to the "Condition of Education" report (2019) about $95 \%$ of students ages 6-21 served under IDEA in autumn 2017 were enrolled in regular schools. Some $3 \%$ of students served under IDEA were enrolled in separate schools (public or private) for students with disabilities; $1 \%$ were placed by their parents in regular private schools; and less than $1 \%$ were homebound or in hospitals, in separate residential facilities (public or private), or in correctional facilities. In other words, US law provides different ways of obtaining special education for students with special needs, including full and partial inclusion in public schools, public and private special education institutions, home schooling, medical institutions, specialized rehabilitation centers and correctional facilities.

The Department of Education of the UK (Special educational needs in England, 2019) also states, that students with special educational needs study in different types of schools: state-funded primary $(51 \%)$ and secondary $(31 \%)$ schools, state-funded special schools $(10 \%)$, pupil referral units $(1 \%)$, independent schools (7\%). The mentioned data are the evidence of existing separate state-funded special schools in both countries and the lack of information about the current world experience in special education among Ukrainian authorities on education.

It is also crucially important for a successful research on comparative studies and for implementation of foreign experience to take into account divers historical, cultural and linguistic traditions and development aspects of the objects and phenomena of education in different countries. Failure to use proper concepts and terms, their interpretation, thoughtless transfer of definitions from one cultural field to another can lead to amusing (and sometimes catastrophic for the development of the educational system) consequences.

For example, the International Standard Classification of Education (1997) replaced the term "special education" with "special needs education" in order to differentiate modern interpretation from the previous one, which meant education only in the separated special education institutions. Because the formation and development of special education in the United States was mainly based on secondary education institutions and no change occurred, the education of children with special needs in this country has traditionally been called "special education". Other English-speaking countries later 
introduced this experience, so to differentiate the concepts the terms "special needs education", "students with special educational needs" are used there.

Hereafter we refer the term "special education" with the meaning "the system of education of students with special needs", since this term is used with this meaning in the United States.

Until recently, the terms "defectology", "correctional pedagogy" and "correctional education" were used in Ukraine to refer to the field of knowledge, which studies the theory and practice of education of persons with disabilities. It should be noted that the direct translation of "correctional pedagogy" from English primarily means "dealing with deviant behavior in the correctional settings". Given the fundamental difference of meaning, we consider it necessary to use the term "special education" in Ukraine to clearly delineate the field of activity and avoid misunderstandings with foreign colleagues (Shevtsov, 2019).

Here is another, in our view, illustrative example. Realizing the idea of the US special education system founder Elizabeth E. Farrell, the US Congress adopted the laws on individuals with disabilities education focused on enhancing their educational achievements through the introduction of the Individualized Education Plan/Program (IEP). The corresponding document in the Law of Ukraine "On Education" (2017) is entitled "Individual Development Plan". Thus, as noted in our previous studies (Shevtsov, 2019), the term introduced by E. Farrell in the United States 120 years ago is used in the Law of Ukraine "On Education" (2017) as well as in the whole Ukrainian special education system with a different meaning. There is a change of concepts that resonates with world terminology (see Table 1): in order to preserve the content of the term "Individualized Education Plan" one should translate into Ukrainian as "Individual Development Plan". However, the term "Individual Development Plan" does not correspond the term "Individualized Education Plan" due to the lack of professional component in the Ukrainian version.

Table 1

An example of the dissonance of ukrainian and american titles of education documents

\begin{tabular}{|c|c|}
\hline $\begin{array}{l}\text { Title and description of a document } \\
\text { introduced in the United States }\end{array}$ & $\begin{array}{l}\text { Title and description of a document } \\
\text { introduced in Ukraine }\end{array}$ \\
\hline $\begin{array}{l}\text { Individualized Education Plan (IEP) is a } \\
\text { document in which a team led by a special } \\
\text { education teacher identifies the specific short- } \\
\text { and long-term goals of the physical, mental } \\
\text { and academic development of each child with } \\
\text { special needs, which is constantly reviewed } \\
\text { and adjusted }\end{array}$ & $\begin{array}{l}\text { Individual Development Program is a document } \\
\text { that provides the individualization of instruction } \\
\text { for a person with special needs, sets out a list of } \\
\text { necessary psycho-pedagogical and corrective needs / } \\
\text { services for the development of the child and is } \\
\text { developed by a team of professionals with the } \\
\text { mandatory involvement of the child's parents to } \\
\text { identify specific educational strategies and } \\
\text { approaches }\end{array}$ \\
\hline $\begin{array}{l}\text { Individual Development Plan (IDP) is a self- } \\
\text { development and professional development } \\
\text { plan for the immediate future that is made for } \\
\text { each student in the school. }\end{array}$ & $\begin{array}{l}\text { Individualized Education Plan is a document } \\
\text { that determines the sequence, form and pace of } \\
\text { a student's learning for the purpose of } \\
\text { implementing his/her individual educational } \\
\text { trajectory, which is developed by the } \\
\text { educational institution in cooperation with the } \\
\text { student, if the needed resources are available. }\end{array}$ \\
\hline
\end{tabular}


sciendo Порівняльна професійна педагогіка 9(4)/2019 Comparative Professional Pedagogy 9(4)/2019

Regarding the methodology of comparative analysis of education systems, many different judgments on this issue were made by O. Lokshyna (2014), A. Sbrueva (1999), A. Shevtsov (2003), S. Sysoieva (2014), A. Vyhrusch (2015), B. Woolfson (2003), and many others). Analyzing the literature, we define the following methodological approaches to educational comparative studies in the field of our studies on special education teachers' training:

- cultural and historical or civilizational approach observes objects, phenomena and educational processes through the lens of a synergistic set of all factors and forms of human vitality and creativity in a civilizational dimension (material, social, political, cultural, religious, ideological, moral, ethic, scientific, etc.)

- system-synergetic approach being an epistemological unity joins systematic and synergistic methodology of educational objects researching as complex, open and nonlinear self-organizing systems (Shevtsov, 2003).

- definitive approach respects different interpretations of objects and phenomena of educational systems and processes across concepts and terms;

- regulatory approach provides analysis of legislative documents, educational standards and recommendations defining the activity of educational system subjects and setting standards, in particular for staff training;

- personal-anthropological approach studies educational phenomena development in the terms of individual's needs and interests' evolution as a significance of a their culture development in the historical dimension;

- ambivalent approach provides for a specific analysis of educational phenomena and processes in the event of their contradictions and the dual nature of their course through different historical, cultural, socio-economic, religious and ideological traditions in different countries;

- synchronous approach involves understanding of the educational process unfolding in relation to other civilizations and regions; and

- diachronic approach considers and compares pedagogical facts and phenomena occurring in different cultural and historical cycles within one civilization area (Sbrueva, 1999).

Anatolyi Vykhroosch (2005) warns beginners in the field of educational comparative studies against "chaotic accumulation of concepts" and haphazard description of different countries. He is assisted by the other researches insisting on scientifically sound structure of such studies (N. Lavrychenko, L. Puhovska, A. Sbrueva, O. Zabolotna and others). Here we can talk about a specific model of educational comparative studies with its specific elements, the functional relationships between them, the criteria and indicators that fit those elements. We manage that the system of these elements of our research must be homomorphic to the considered education systems.

Many works are devoted to the structures of education systems at different levels (Andreyev (2002), M. Bray, Ph. H. Coombs, M. Crossley, B. Holmes, G. P. Kelly, I. Podlasyi (1999), I. Radchenko (1989), A. Shevtsov (2009) and others). We agree with the statement of V.O. Slastionin (2002), who underlines the complexity of the issue of pedagogical systems elements and absence of the common approach to their defining among the researchers because the choice of these elements (subsystems) may have different reasons and is "an intuitive and creative act in a certain extend". However, let us first give our analysis of some education system structures determined by other researchers.

The elementary structure of the typical education system the traditional educational process is carried out in is commonly represented with the following 
interconnected set of invariant elements: 1) the purpose of education; 2) the content of education; 3) students; 4) teachers; 5) methods; 6) funds; 7) forms of training. This simple scheme enables researches on education systems as coherent pedagogical phenomenon considering all socio-economic and historical factors.

Developing the issues of so-called informational and educational environment, A. Andreyev (2002) adds to this system its functional subsystems: financial and economic, logistical, regulatory, marketing and managerial.

An American teacher Ph. H. Coombs in the book "The World Educational Crisis: A Systems Analysis" (1968) defines the main components of an education system: 1) aims and priority tasks (determine the systems activity); 2) students' education (the main task of the system); 3) management (coordinates, directs and evaluates the system activities); 4) structure and time management (according to different tasks); 5) content (the main thing that students receive from education); 6) teachers; 7) educational tools (books, maps, films, laboratories, etc.); 8) educational premises necessary for the educational process; 9) technology (all techniques and methods used in training); 10) evaluation and assessment of obtained knowledge and skills (admission rules, assessment, exams, quality of training); 11) research work (to increase knowledge and improve the system); 12) costs of system.

Professor I. Radchenko (1989) identifies the following components in the education system: 1) goals and objectives that determine the activity of the system; 2) the content of education; 3) pedagogical staff providing the realization of the goals and objectives on the content of education; 4) scientific staff providing scientifically sound system functioning, continuous improvement of the content and methods of organization of training and education at the level of modern requirements; 5) students whose education is the main task of the system; 6) logistics (premises, equipment, technical equipment, manuals, etc.); 7) financial support of the system and its performance indicators; 8) conditions (psychophysiological, hygienic, aesthetic and social); 9) organization and management.

I. Podlasyi (1999) notes that educational process as a system is not identical to the system in which this process takes place and observes the system of public education in general, a school, a class, a lesson, etc. Each of these education systems operates in certain external conditions: natural, social, industrial, cultural, etc. The following are internal conditions: logistics, sanitary, moral, psychological, aesthetic and others.

In our book "Educational Basics of Rehabilitation" (Shevtsov, 2009, pp. 461-481) we have identified the following components of the national system of rehabilitation of individuals with disabilities: rehabilitation institutions and establishments, correctional and rehabilitation services, organizational forms of rehabilitation, methods and technologies of rehabilitation, legislative and regulatory subsystem, information and scientific subsystems, financial subsystem, moral, religious and political principles of society, etc.

It is obvious that the structure of the national rehabilitation system elaborated in the mentioned work can be taken into account for solving our task, since the rehabilitation system and the education system on the national level have similar goals and means of their achieving, since both are human-centered systems.

So, in order to fulfill our task - to carry out a comparative analysis of the development of special education teacher preparation systems in the USA, the UK and Ukraine - we select the following elements for our comparative study (at the same time we will also call the criteria for the development of these systems):

1. Legal support of the educational system for individuals with special needs.

2. National and regional standards of special education teacher preparation. 
sciendo Порівняльна професійна педагогіка 9(4)/2019 Comparative Professional Pedagogy 9(4)/2019

3. Curriculums, methods, and technologies for special education teachers' preparation.

4. System of retraining and licensure of special education teachers.

5. Informative and scientific subsystem of special education system.

6. Subsystem of special education teachers' pre-service preparation and in-field practical work management.

7. Financial and economic subsystem of training and retraining of special education teachers.

In the following we provide some facts on the US special education for these criteria of analysis applying.

Desperate efforts of educated practitioners, volunteers, doctors, politicians, community activists, and parents eventually found legislative approval that resulted in the adoption of federal and state regulations for the purpose of introducing special approaches to education of students with disabilities in public schools in the United States.

More than a century ago, American schoolteacher Elizabeth E. Farrell first came up with the original idea to teach underachieving children in the public schools basing on a program of individualized instruction (Kode, 2017). The practical implementation of this idea was the launching of an "ungraded" class of 19 students aged 8-16. These were students from all over the school that no one could cope with: twelve of them were diagnosed with intellectual disabilities, several had problems with the law, and some were migrants. An established one ungraded class institution led to a whole network creation: in 1911, there were already 131 ungraded classes in New York. In this way the first ungraded class created by E. Farrell became the successful model for similar programs of individualized instruction throughout the United States and, later, the basis for the US current special education system. In 1906, E. Farrell established an executive body to coordinate the activities of all classes for underachieving students - the Department of Ungraded Classes at the Department of Education in New York City - and became its first director (Kode, 2017).

E. Farrell was well aware of the professional communication importance and sharing of experience to optimize teachers' work. In 1915, she founded the magazine Ungraded to promote special education and encourage practitioners to share their experiences with such children. In 1922, she founded a professional organization - the Council for Exceptional Children (CEC) - and became its first president.

Thus, the majority of sources on the US special education organization state only one date -1975 . Thanks to active equal civil rights movement for all citizens of the country, that year the US Congress adopted "The Education for All Handicapped Children Act", which provided access for American children with special educational needs from 3 to 21 years to free proper quality education in the least restricted environment, as well as addressing other organizational and financial issues on their education.

As a result of a careful study of the legislation passed by the US Congress in different years, we have been able to find a number of other laws that directly relate to improving the lives of persons with disabilities, their education and training teachers to work with them. In particular, updates to the "Individuals with Disabilities Education Act" (IDEA, 2004) (1990, 2001, 2004) and "No Child Left Behind Act" (NCLB) (2001) provided equal access for all students with special needs, including those with severe disabilities, to adequate public education. In the United States, as a whole, about forty acts (including amendments to them) have been adopted so far that regulate the organizational and financial issues of special education, as well as the preparation of pre-service special education teachers. 
sciendo Порівняльна професійна педагогіка 9(4)/2019 Comparative Professional Pedagogy 9(4)/2019

For example, the "Individuals with Disabilities Education Act" (IDEA, 2004) provides for innovations for various subjects of influence: students should exercise this right, teachers should prepare for the provision of educational services in the context of inclusive education, higher education institutions in the training of future teachers should take into account such need, update and train curricula; special education institutions should anticipate the educational and domestic needs of their actual and potential students and provide all necessaryю Finally, the departments of education should work with the parents of these children to ensure that the child is provided with a civic education that is as close as possible to the quality of the students' education without limitation of life.

In addition, there may be different innovations for each legal entity:

- for persons with disabilities: introduction of a new terminology for the designation of psychophysical disorders on the principle of "individual first" "individual with intellectual disabilities" instead of "mentally retarded"); two categories of pupils with special educational needs are added (persons with autism and persons with traumatic brain injuries); allowed to sue the states for failure to comply with the law;

- for teachers: the need to introduce early development programs for infants and young preschoolers with delayed psychophysical development;

- for educational institutions: social work and rehabilitation counseling services are related to additional related services in special education institutions, etc.

Thus, the objects of influence are closely interconnected and constitute a single system of special education. All types of objects are affected by regulations adopted under the influence of social, economic and political factors that so regulate the special education system

Nowadays the Council for Exceptional Children is the largest international organization of educators, which defines the policy of educating children with special educational needs, in particular the gifted, at the global level. The standards for special education teachers defined to be the Council's primary goals in the 1920s are constantly being improved to ensure the quality training of all professionals working with special needs students.

Higher education institutions are developing educational programs for effective special education teacher preparation in accordance with standards, for example "The Preparation Standards" developed by the Council for Exceptional Children (CEC). These are current, research-based, universal standards, fully address the knowledge and skills special education teacher must obtain. CEC introduced two types of the Preparation Standards: Initial Preparation Standards (Learner Development and Individual Learning Differences; Learning Environment; Curricular Content Knowledge; Assessment; Instructional Planning and Strategies; Professional Learning and Ethical Practice; Collaboration) and Advanced Preparation Standards (Assessment; Curricular Content Knowledge; Programs, Services and Outcomes; Research and Inquiry; Leadership and Policy; Professional and Ethical Practice; Collaboration). The mentioned standards are used by all training programs whatever the specialty area. Thus, the Preparation Standards do not outline specialized content for settings of different specialty areas.

To differentiate disabilities, licensing features in different states, and the roles of special education teachers, "CEC Knowledge and Skills Specialty Sets" were introduced. Since 1984, CEC has developed 11 Initial Specialty Sets (Blind and Visual Impaired; Deaf and Hard of Hearing; Deafblindness; Developmental Disabilities and Autism Spectrum Disorder; Early Childhood Special Education / Early Intervention; Emotional and Behavioral Disorders; Individualized General Curriculum; Individualized Independence Curriculum; Individualized General Curriculum and Individualized Independence Curriculum, combined; Learning 
sciendo Порівняльна професійна педагогіка 9(4)/2019 Comparative Professional Pedagogy 9(4)/2019

Disabilities; Physical, Health and Multiple Disabilities) and 12 Advanced Specialty Sets (Special Education Academic Intervention Specialist; Special Education Administration Specialist Set; Special Education Behaviour Intervention Specialist; Special Education Deaf and Hard of Hearing Specialist; Special Education Developmental Disabilities and Autism Spectrum Disorder Specialist; Special Education Diagnostician Specialist; Early Childhood Special Education/Early Intervention Specialist; Special Education Inclusion Specialist; Special Education Learning Disabilities Specialist; Special Education Technology Specialist; Special Education Transition Specialist) and two separate sets: Field Experience and Clinical Practice Standard and Initial / Advanced Preparation Standards for Gifted Education Professionals.

For each of the specializations at the bachelor's and master's levels, the training of special education teachers should correspond to a single list of standards. The standard characteristics and its key components are different at each level of preparation.

\section{CONCLUSIONS}

The modernization of the national educational system in Ukraine in the framework of the world mainstream is not possible without unified and well-defined terminological bases, methodological foundations, principles and criteria for comparative studies that meet the current level of the science development and the needs of society, the definition of which we define as the purpose of our further researches. In order to carry out our comparative study on the development of special education teacher's preparation systems in the USA, the UK and Ukraine we have selected and proved the criteria to be used: legal support of the educational system for individuals with special needs; national and regional standards of special education teachers' preparation; curriculums, methods, and technologies for special education teachers' preparation; system of retraining and licensure of special education teachers; informative and scientific subsystem of special education system; subsystem of special education teachers' pre-service preparation and in-field practical work management; financial and economic subsystem of training and retraining of special education teachers. Further research should reveal didactic principles of educational comparative studies on special education teachers' preparation in the foreign experience.

\section{REFERENCES}

1. Andreyev, A. A. (2002). Pedagogika vysshey shkoly: Novyi kurs. Moscow: Moscow International Institute of Econometrics, Informatics, Finance and Law.

2. Coombs, Ph. H. (1968). The World Educational Crisis: A Systems Analysis. Oxford: Oxford University Press.

3. Conditions of Education: Children and Youth with Disabilities. (2019). National Center for Education Statistics. Retrieved from https://nces.ed.gov/programs/coeindicator_/ cgg.asp.

4. International Standard Classification of Education. (1997). Retrieved from http://www.oecd.org/education/skills-beyond-school/1962350.pdf.

5. Individuals with Disabilities Education Act (IDEA)). (2004). Public Law 101476. Retrieved from https://www.govinfo.gov/content/pkg/USCODE-2011-title20/pdf/ USCODE-2011-title20-chap33.pdf.

6. Kode, K. (2017). Elizabeth Farrell and the History of Special Education. Washington: Council for Exceptional Children.

7. Lokshyna, O. (2014). Porivnialna pedahohika: dosiahnennia dvohsot rokiv rozvytku ta sychasni problem. Porivnialno-pedahohichni studiyi, 3-4, 6-15. 
sciendo Порівняльна професійна педагогіка 9(4)/2019 Comparative Professional Pedagogy 9(4)/2019

8. Luhovyi, V. I. (1994). Pedahohichna osvita v Ukrayini: structura, funktsiyi, tendentsiyi rozvytku. Kyiv: MAUP.

9. No Child Left Behind Act (NCLB). (2001). Retrieved from https://www2.ed.gov/ policy/elsec/leg/esea02/index.html.

10. Ogneviuk, V. O., \& Sysoyeva, S. O. (2012). Osvitolohiya - naukovyi napriam integrovanogo doslidzhennia sfery osvity. Ridna shkola, 4-5 (988-989), 44-51.

11. Podlasyi, I. P. (1999). Pedagogika: novyi kurs. Moscow: VLADOS Center.

12. Radchenko, I. P. (1989). NOT uchitelia. Moscow.

13. Sbruyeva, A. A. (1999). Porivnialna pedahohika. Sumy: SDPU Editorial and Publishing Department.

14. Shevtsov, A. (2003). Synerhetychni pryntsypy proektuvannia pedahohichnoho protsesu yak systemy. Vyscha osvita Ukrayiny, 2, 115-119.

15. Shevtsov, A. G. (2009). Osvitni osnovy reabilitolohiyi. Kyiv: SP Lesya.

16. Shevtsov, A. G., \& Nykonenko, N. V. (2019). Do pytannia pro porivniannia poniatiyno-terminolohichnoho polia haluzi spetsialnoyi osvity $\mathrm{v}$ ukrayinskiy ta angliyskiy movakh. Aktualni pytannia korektsinoyi osvity, 13, 324-340. Academy.

17. Slastenin, V. A. (ed.), Isayev, I. F., \& Shiyan, E. N. (2002). Pedahohika. Moscow:

18. Special educational needs in England. (January 2019). Retrieved from http:/assets./ publishing.service.gov.uk/government/unloads/system/uploads/attachment_data/file/81424 4/SEN_2019_text.docx.pdf.

19. Sysoyeva, S. O. (2014). Porivnialna pedahohika v konteksti rozvytku osvitolohiyi. Methodologichni zasady osvity, 3, 17-23.

20. Vykhroosch, A. (2015). Pomylky v metodolohiyi komparatyvistyky. Pedagogichna Komparatyvistyka - 2015: Transformatsiyi v osviti zarubizhzhia ta ukrayinskyi kontekst. Kyiv: Pedagogichna Dumka.

21. Woolfson, B. L. (2003). Sravnitelnaya pedagogika: istoriya i sovremennyie problemy. Moscow: URAO Press.

22. Zakon Ukrainy "Pro osvitu. (2017). 